\title{
New Proposals for the Design of Integrated Online Wine Industry Dictionaries
}

\author{
Patrick Leroyer, School of Business and Social Sciences, Centre for \\ Lexicography, Aarhus University, Aarhus, Denmark (pl@asb.dk)
}

\begin{abstract}
The specialised lexicographic treatment of oenology and viticulture usually consists in the compiling of articles describing the language of wine in general language dictionaries, or presenting professional knowledge of wine in specialised multi-field dictionaries and encyclopedias. This treatment also encompasses the terminological compilation of single field dictionaries describing the language and/or knowledge of wine. Lexicographically speaking, all this is but a fraction of the complete picture. Indeed, the specialised lexicography of oenology and viticulture is multifaceted and goes far beyond the above-mentioned types of articles and dictionaries. It includes a broad range of both online and printed lexicographically structured information tools, such as wine guides, atlases, companions, oenological websites, and mobile applications. In line with this growing interest for lexicographically structured information tools on oenology, wine making, and wine tasting, this article argues for an expansion of lexicography dealing with wine: It explains how a new lexicographic information tool, in this case OENOLEX Burgundy, a French monolingual online wine dictionary commissioned by the Burgundian wine industry, offers various functions and usage modes to its users, including access to multimodal data, and how it differs from a comparable South African online wine dictionary commissioned by the South African wine industry. In line with the findings of this comparative study, lexicographic proposals are subsequently formulated. The first proposal is that such online wine industry dictionaries should be developed in accordance with specific user situations and needs, and make use of a monofunctional design and an adaptive user interface. The second proposal is that such online wine industry dictionaries should not stand alone, as they could benefit from a full integration with the websites of the wine industry, and consequently transform into genuine lexicographic information tools.
\end{abstract}

Keywords: SPECIALISED LEXICOGRAPHY, SPECIALISED DICTIONARIES, ONLINE SPECIALISED DICTIONARIES, SUBJECT-FIELD-BASED DICTIONARIES, USER-SITUATIONBASED DICTIONARIES, FUNCTION THEORY OF LEXICOGRAPHY, WINE INDUSTRY DICTIONARIES, CONSULTATION, NAVIGATION, ACCESS MODES, MULTIMODALITY, USER NEEDS PARADIGM, WEBSITE INTEGRATION

Opsomming: Nuwe voorstelle vir die ontwerp van geïntegreerde aanlyn wynbedryfwoordeboeke. Die gespesialiseerde leksikografiese behandeling van die wynkunde en wynbou bestaan gewoonlik in die samestelling van artikels wat die taal van wyn in algemene taalwoordeboeke beskryf of die vakkennis van wyn in gespesialiseerde multiveldwoordeboeke en -ensiklopediëe aanbied. Hierdie behandeling omvat ook die terminologiese samestelling van enkelveldwoordeboeke wat die taal en/of kennis van wyn omskryf. Leksikografies gesproke is 
dit alles maar ' $n$ klein deeltjie van die geheelbeeld. Die gespesialiseerde leksikografie van die wynkunde en wynbou is inderdaad ryk geskakeerd en gaan ver verby die bogenoemde soort artikels en woordeboeke. Dit sluit ' $n$ wye reeks van sowel aanlyn as gedrukte leksikografies gestruktureerde inligtingsgereedskap in, soos wyngidse, -atlasse, -maatskappye, wynkundige webtuistes en mobiele toepassings. Ooreenkomstig hierdie groeiende belangstelling vir leksikografies gestruktureerde inligtingsgereedskap oor wynkunde, wynmaak en wynproe, bepleit hierdie artikel 'n uitbreiding van die leksikografie wat handel oor wyn: Dit verduidelik hoe 'n nuwe leksikografiese inligtingswerktuig, in hierdie geval OENOLEX Burgundy, 'n Franse eentalige aanlyn wynwoordeboek wat 'n opdrag van die Boergondiese wynbedryf is, verskillende funksies en gebruiksmodusse aan sy gebruikers bied, insluitende toegang tot multimodale data, en hoe dit verskil van 'n vergelykbare Suid-Afrikaanse aanlyn wynwoordeboek wat 'n opdrag is van die Suid-Afrikaanse wynbedryf. Ooreenkomstig die bevindinge van hierdie vergelykende studie, word leksikografiese voorstelle vervolgens geformuleer. Die eerste voorstel is dat sulke aanlyn wynbedryfwoordeboeke ontwerp behoort te word in ooreenstemming met spesifieke gebruikersituasies en -behoeftes en gebruik te maak van 'n monofunksionele ontwerp en 'n aanpasbare gebruikerskoppelvlak. Die tweede voorstel is dat sulke aanlyn wynbedryfwoordeboeke nie alleen behoort te staan nie, aangesien hulle kan baat by 'n volle integrasie met die webtuistes van die wynbedryf, en gevolglik verander in werklike leksikografiese inligtingsgereedskap.

Sleutelwoorde: GESPESIALISEERDE LEKSIKOGRAFIE, GESPESIALISEERDE WOORDEBOEKE, AANLYN GESPESIALISEERDE WOORDEBOEKE, ONDERWERPSVELDGEBASEERDE WOORDEBOEKE, GEBRUIKERSITUASIEGEBASEERDE WOORDEBOEKE, FUNKSIETEORIE VAN DIE LEKSIKOGRAFIE, WYNBEDRYFWOORDEBOEKE, RAADPLEGING, NAVIGASIE, TOEGANGSMODUSSE, MULTIMODALITEIT, GEBRUIKERSBEHOEFTESPARADIGMA, WEBTUISTE-INTEGRASIE

\section{Introduction: The specialised lexicography of oenology and viticulture within the user needs paradigm}

As a subject field, wine represents the world's universal cultural heritage. In terms of economy, it is an influential industry representing a large number of stakeholders such as wine growers, wine makers, and wine merchants. As an object of consumption, wine is probably becoming one of the most popular lifestyle-determined subjects of interest and curiosity in the minds of global hyperconsumers of today (Lipovetsky 2006). Paper-based wine dictionaries (DLV 2007), wine encyclopedias, wine atlases, wine companions and wine guides (GHV 2010) have become increasingly popular and are now being rapidly replaced by online resources, such as professional online wine dictionaries (Winetech and Sawis 2012), huge encyclopedic articles and portals (Wikipedia 2013), and online wine guides (GHV 2013), to name just a few. The transition from the paper form and the main principles of online lexicography have been thoroughly described in Granger and Paquot (2012), Fuertes-Olivera and Bergenholtz (2011a and 2011b), Tarp (2012) and Fuertes-Olivera and Tarp (2014), all of whom advocate user-oriented solutions based on user needs. Also, the 
Internet as a prolific source of information on wine provides access to a vast number of word lists, glossaries, and online wine dictionaries of varying quality. The development of mobile information technologies for smartphones has led to a vast expansion of the volume and types of data which users look for to satisfy their information needs. It has also brought about a multiplication of access modes (Leroyer 2011; Leroyer and Gouws 2009). A smartphone App such as Drync Wine Free and Pro (2013) gives fast and easy access to information about 1,2 million wines, 100.000 score cards written by wine tasting oenologists, and a plethora of oenological information, including advice on how to buy wine and virtually manage one's own wine cellar.

Common to all these information resources, perhaps with the exception of the Drync wine App, is the fact that they seem to privilege a subject field perspective rather than the user needs perspective. In other words, it seems that the presentation of data supporting communication about wine or knowledge of wine per se tends to become the aim of the resource. The process of data selection is normally guided by a description of wine as a subject field, or a range of major subject-fields and a large number of associated subfields. From a functional perspective, and in line with Fuertes Olivera and Tarp (2014), one should think that compiling a wine dictionary should start with an analysis of the social situations in which information needs about wine can lead to the consultation of specific kinds of wine dictionaries or other wine-related lexicographic information tools. This calls for an approach based on user needs and user situations, one in which lexicographic functions have a major role to play. Should the tool help its intended users to communicate about wine, to acquire knowledge of wine, to interpret non-verbal signs and codes such as the complex information provided by wine labels, or to carry out wine-related mental and physical operations, such as wine tasting? The implementation of the functions should start with the lexicographic identification of the unique social situations which are characteristic of the information society, then analyze the complex of specific information problems and information needs related to these situations, and determine the extent to which potential information needs arising from the situations can be met and gratified by a lexicographic information tool. In many cases, the lexicographic situation will only have been partly, if at all, recognised as such before.

This article consists of three parts. First, it presents the Function Theory of specialised lexicography and confirms the pre-eminence of the social situation in the extra-lexicographic world. Second, a South African online wine industry dictionary is reviewed as a case of a predominantly subject-field-based dictionary, and proposals for improvement are made. Third, a new user-situation- and user-need-based dictionary of wine, currently under construction, is presented, and new proposals for the development of online wine dictionaries in general are finally formulated. Although different in scope, the two online dictionaries share the same functions, which is to help users in training situations.

The basic lexicographic methodology underlying the present research was 
previously introduced in Leroyer (2008 and 2011), and in Gouws and Leroyer (2009) (regarding the transformation of guides into lexicographic information tools), and in Leroyer and Gouws (2009) (regarding the compilation of a new kind of website integrated online wine guide and dictionary).

In conclusion, it is claimed that user-based specialised lexicography taking the specific wine-related social situations as a point of departure for dictionary design and dictionary compiling could have a substantial impact on the development of integrated online wine industry dictionaries of tomorrow.

\section{The lexicographic functions of specialised dictionaries}

There are four basic elements that constitute the core of the Function Theory of lexicography (Fuertes-Olivera and Tarp 2014; Tarp 2008a and 2008b). Dictionaries and other lexicographic tools are built to satisfy punctual information needs. As tools, they have functions which are essential to their genesis and to their use. According to Bergenholtz and Tarp 2010, a lexicographic function is defined as:

(a) the satisfaction (through the selection and presentation of easily accessible data)

(b) of the specific types of lexicographically relevant needs that may arise

(c) in a specific type of potential user

(d) in a specific type of extra-lexicographic situation.

Information needs are lexicographically relevant in so far as they can be satisfied by consultation. Bergenholtz and Tarp (2010: 30) state: Not all situations are relevant for lexicography; only situations in which needs may arise that can be satisfied by consulting dictionaries. This statement should actually be slightly modified by adding: and other lexicographic information tools. Accordingly, the lexicographer's task is to pinpoint the specific user needs in the specific use-situations, and to establish the user profiles. This analysis should lead to the design of a unique dictionary concept, in which selection and presentation of easily accessible data will lead to the satisfaction of the needs.

User-based specialised lexicography begins by acknowledging the primacy of the situation. A definition of lexicography could thus be that it is a discipline dedicated to the construction of functional lexicographic information tools for the satisfaction of information needs in specific types of social situations in the extra-lexicographic world, combining types of social situations, types of user needs, and types of users. The primacy of the social situation can then lead to the invention of new lexicographic concepts and the development of corresponding functional configurations, the implementation of innovative data selection and presentation principles with integrated solutions, and the implementation of innovative access options on multiple platforms and termi- 
nals, including mobile solutions.

From a functional perspective, subject-based specialised lexicography normally includes three fundamental, major steps:

(a) In the recognition phase, the lexicographer takes the recognition of a preexisting subject-field and associated subfields as a point of departure (cf. Bergenholtz and Kaufmann 1997).

(b) In the transformation phase, the lexicographer critically transforms existing subject-field-based dictionary concepts into new ones by applying adequate lexicographic functions.

(c) Finally, in the implementation phase, the lexicographer compiles a lexicographic information tool according to the functions.

Situation-based specialised lexicography is also characterised by three fundamental steps, but the point of departure is the social situation itself, i.e. the user needs, not the subject-field:

(a) In the identification phase, the specialised lexicographer takes the identification of a unique social situation as a point of departure.

(b) In the invention phase, the specialised lexicographer can invent new configurations of the lexicographic functions.

(c) Finally, in the innovation phase, the lexicographer can compile an innovative lexicographic tool taking advantage of the new functional configurations.

The above stated two sets of lexicographic principles - subject based and situation based - will now be applied in the comparative study of two online wine industry dictionaries in the following sections.

\section{Subject-field-based wine industry dictionary: The SAWIS South Afri- can Trilingual Dictionary of Wine}

The South African Trilingual Wine Industry Dictionary - SATWID (Winetech and SAWIS 2013) is an online wine industry dictionary of oenology and viticulture. It contains the central wine terminology used by the South African wine industry and covers numerous subject fields and subfields related to wine. All terms are lemmatised in English and translated into Afrikaans and Xhosa. The terminology of wine tasting, for instance, includes 228 entries. All terms are provided with subject field labels indicating the specific field or subfield to which they belong. For example, the subject field "viticulture" includes a number of subfields, such as "organic growth and production", "soil science", "plant biotechnology", "vine viruses" and "plant improvement". The subject field "oenology" encompasses the terminology of production technology, bottling, 
packaging and distribution, as well as microbiology. This subject field approach is confirmed by a subject-field-based access to data through the list of subject fields: By clicking on a specific subject field label/link from the list in the right panel, users can get access to the complete list of terms included in the field. Linguistic information, including information on part of speech is also provided, but only in English so far. It is foreseen that the information will also be provided in Afrikaans and Xhosa at a later stage of the project.

The metalexicographic description of SATWID, i.e. the introduction and instructions, seems to contain a number of inconsistencies as far as user profiles, target users, and functions are concerned. According to the compilers of the dictionary, one of its purposes is to assist its intended users in learning situations in order to fulfil their educational needs:

Emerging producers and people who do not have training or a background in the industry can be assisted by this dictionary. It fulfils a training and introductory function and can fulfil the educational needs of the user with explanations of terms that are used in the industry.

In line with Fata (2010), one should expect then that the SATWID should make provision for assistance in connection with cognitive situations, as knowledge acquisition is the central element of any training program (see also FuertesOlivera 2010). However, the SATWID is defined as communication-oriented, and no mention at all is made of cognitive functions:

The dictionary is multi-functional, i.e. it can be used for text production, text reception and text translation.

Whereas the intended users, in accordance with the genuine purpose of the dictionary, are clearly identified as semi-experts in the background information on the dictionary:

Emerging producers and people who do not have training or a background in the industry,

the actual users are said to consist of both experts (the first four categories listed below) and semi-experts (the following five ones); moreover, wine lovers probably belong in many cases to the category of lay people:

Viticulturists and oenologists, producers and wine makers, viticulture and oenology students and lecturers, public relations officers and information officers, wine marketers, wine writers, wine lovers.

These users have very different profiles and are engaged in a large number of various social situations related to wine (wine growing, wine making, learning about wine, promoting wine, selling wine, writing about wine — or simply being interested in wine in general and having a desire for information in the case of wine lovers), in which lexicographic information needs can arise. It might be feared then than the fulfilment of the lexicographic aims cannot be 
achieved, because the different user profiles have basically very different lexicographic information needs owing to their diverging background, general culture and level of knowledge, and because they are engaged in radically different user situations. The functional shortage of the SATWID is probably due to a systematic, subject-based approach, which must have been commissioned by the industry for which the dictionary is a tool of interlingual communication and standardisation. The dictionary is not really user-based; it is a list of expert words for experts of different fields. As for language planning purposes, including terminologisation patterns and solutions (for Xhosa), text production and translation, the data prove clearly insufficient. Grammatical information is limited to parts of speech, and the dictionary does not offer any information on collocations. Only terms of the wine industry are lemmatised in English and translated into Afrikaans and Xhosa (English white wine, Afrikaans witwyn, Xhosa iwayini emhlophe), although a small number of culture-dependent items are also included, such as wine route (see below).

The article presented below illustrates one of the basic problems of the subject-based approach. The meaning of the lemma wine route is categorized and specified by the label 'commerce', but strangely enough not by the label 'wine tourism' or 'oenotourism', which would be much more appropriate. Besides, no references are made to South African wine routes, so the information value of the article is limited for those users who participate in a wine training program and definitely need such information to acquire knowledge of this crucial aspect of the South African wine industry and wine culture.

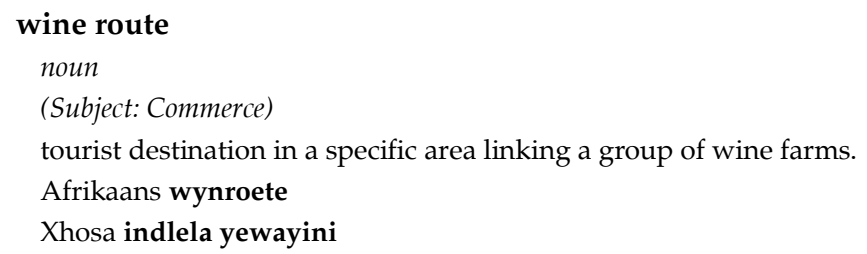

One of the most striking features of the SATWID is the fact that the lexicographic data are largely generic (according to its compilers: 'physiology and fruit of the vine, winemaking processes') in so far as they are subject-fieldbased. The data are not really specific to South Africa, apart from the fact that the dictionary consists of English lemmas and articles translated into Afrikaans and Xhosa. As such, the SATWID can be effectively used for language planning purposes, included standardisation, but there seems to be paradoxically very little specific South African information in it: For instance, it does not provide any encyclopedic information on South African varieties of grapes (Bukettraube, Cape Riesling, Hanepoot, Roobernet, or Pinotage, the local cross between Pinot Noir and Cinsaut, which is unique to South Africa) nor on any other crucial cultural aspects of viticulture (ethical trade, history, soils, climates, wine of origin legislation). The SATWID offers a link in the right panel, List of varieties $>>$, but this link unfortunately does not give direct access to the 
list. The access is unnecessarily intricate. Users have to click on a series of various links and pick up the right heading in the navigation panel before they finally can open a PDF document included in a wine-of-origin scheme with all varieties. The varieties should have been lemmatised in the first place.

On the basis of this short review of the SATWID, it is hereby proposed to:

(a) expand, in line with recommendations formulated by Carstensen (1989) and Leroyer and Bergenholtz (2014), the lemma list with culture bound words and expressions which are truly constitutive of the South African wine industry and its unique wine culture; this would include, e.g., the lemmatisation of grape varieties, wine routes, estates, etc.

(b) expand and adapt definitions to the intended target user groups (semiexperts) for text reception functions and for learning, by including relevant encyclopedic explanations and illustrations to the short definitions of the terms,

(c) include collocations and translation of collocations in all three languages to reinforce the text translation functions,

(d) include extended grammatical information to reinforce the text production functions,

(e) include text examples to reinforce the text production functions,

(f) provide internal links to synonyms to secure easier and faster access in connection with the text production functions,

(g) include multimodal data types (illustrations, videos) to improve the cognitive functions, particularly in learning situations,

(h) make the incorporation of the SATWID into the SAWIS homepage (SAWIS 2013) even more visible than it is now in order to secure faster and easier access to the dictionary itself,

(i) include direct links to the different pages and websites of the SAWIS homepage to support cognitive functions in learning situations, or even to the pages of commercial resources such as Wine.co.za 2013, and

(j) provide, whenever relevant in text reception situations, direct links from terms used in the texts of the SAWIS homepage to the definitions provided in the SATWID (opening in new windows).

The above recommendations, which fall into the categories of data selection (more specific data for the foreseen user-situations), access to the data (faster and easier access to the data), and multimodal data (integration of the homepage), would contribute to transform the SATWID, which at present is a predominantly subject-field based dictionary, into a truly user-situation based dictionary. 


\section{User-situation-based wine dictionary: OENOLEX Burgundy}

OENOLEX Burgundy $(\mathrm{OB})$ is an international lexicographic co-operation project between the University of Burgundy in Dijon (France) and Aarhus University (Denmark). The project was commissioned by the BIVB (VDB 2013), the branch organisation of the Burgundy wine industry. The goal of the BIVB was to develop an information tool aimed at the promotion of communication and knowledge about Burgundy wine. More precisely, the decision was made to develop a lexicographic information tool aimed at the information needs of its intended users, in this case sommelier (wine waiter) students and other students following wine tasting courses at the Burgundy wine school. OB was originally commissioned by the BIVB as a so-called nuancier lexicographique, meaning a kind of lexicographic 'colour card' of terms, expressions, and other codes used by the Burgundy wine industry in connection with wine tasting. No matter how strange it may sound for the designation of a lexicographic information tool, what was needed was a lexicographic information tool, no matter what it was called, in line with the statements of Fuertes-Olivera and Tarp (2014):

Specialised lexicographical works may be published under a whole range of different names such as dictionary, encyclopaedia, encyclopaedic dictionary, lexicon, vocabulary, glossary, terminological database, knowledge bank, resource, tool, etc. At the end of the day, it is not these names but the functions of the respective products that determine whether or not they can be considered specialised lexicographical works.

OB includes four types of user situations, all related to wine tasting situations, and their related information needs:

(a) Cognitive situations in which the intended users need to acquire knowledge on the act of wine tasting itself, on the language used to verbalise this act, including knowledge on relations between categories of wine tasting concepts, or on the knowledge of the wine being tasted in order to contextualise the tasting experience.

(b) Communicative situations in which the intended users need assistance in connection with the reception or production of oral texts about wine tasting. The lexicographic challenge here is to provide alternative access routes to the data, so that the user can verbalise their subjective experience of wine tasting properties, one of the main objectives of the teaching being to acquire the competences necessary to make a professional evaluation of the wine.

(c) Operative situations in which the intended user needs assistance in order to perform the operation of wine tasting.

(d) Interpretive situations in which the intended users need assistance in 
order to interpret the types of legal and commercial information printed on the labels of the wine bottles being tasted; the Burgundy wine industry makes use of a very intricate system of "appellations" and "climats" and "lieux dits"t.

Wine tasting evaluation is the result of three phases, which are based on three distinctive sensory experiences: visual, olfactory, and gustatory evaluations. In the following section, the four types of user situations identified for $\mathrm{OB}$ are briefly presented, and the solutions chosen by the compilers of OB to satisfy user needs. Together, these solutions contribute to the realisation of the evaluative function, which is the genuine purpose of $\mathrm{OB}$.

\subsection{Communicative situations}

In $\mathrm{OB}$, the relevant communicative situations are wine tasting situations in which potential tasters of Burgundy wine are confronted with a reception or a production problem in an oral communication situation (to understand speech during a wine tasting lesson or presentation, or to produce an oral text and verbalise sensations in a professional way).

All lexical units directly connected with the evaluative act of tasting Burgundy wines are lemmatised and provided with the following data fields, shown in Table 1 below:

\begin{tabular}{|l|}
\hline lemma \\
\hline lemma subject class \\
\hline lemma grammar \\
\hline definition \\
\hline collocations \\
\hline synonyms \\
\hline antonyms \\
\hline examples \\
\hline references to specific wines on the BIVB website \\
\hline references to relevant web pages on the BIVB website \\
\hline
\end{tabular}

Table 1: Communicative situations

However, the lexicographic problem in connection with wine tasting is more complex. It is necessary to create access routes to resources that are not directly accessible through lemmas, as users (learners) do not (yet) know how to verbalise their evaluation. OB will provide a systematic access to lists of relevant 
wine tasting items, making it possible, for instance, to redirect the search from basic colours to multiple colour shades, from basic fragrances to detailed fragrances, including the evaluation of qualities and faults, or from specific wines to their characteristics. Access is made possible through the systematic organisation of wine tasting concepts, each concept (here floral in table 2 below) being linked to classes of concepts, and to specific wines. The user can also click on the wine itself in order to be re-routed to the website itself, which contains full descriptions of the specific wines $(a, b, c, d, e, \ldots)$

\begin{tabular}{|l|}
\hline impressions \\
\hline \begin{tabular}{l} 
1. olfactory impressions \\
1.1. aromas \\
1.1.1. floral \\
1.1.1.1. jasmine $\rightarrow$ wine $\underline{\mathrm{a}}, \underline{\mathrm{b}}, \underline{\mathrm{c}}, \underline{\mathrm{d}}, \underline{\mathrm{e}}, \ldots$ \\
\\
$\quad$ violet $\rightarrow$ wine $\underline{\mathrm{a}}, \underline{\mathrm{b}}, \underline{\mathrm{c}}, \underline{\mathrm{d}}, \underline{\mathrm{e}}, \ldots$ \\
$\quad$ rose $\rightarrow$ wine $\underline{\mathrm{a}}, \underline{\mathrm{b}}, \underline{\mathrm{c}}, \underline{\mathrm{d}}, \underline{\mathrm{e}}, \ldots$ \\
\hline
\end{tabular} \\
\hline
\end{tabular}

Table 2: Classification of wine tasting terms and linking to specific wines on the website

Wine qualifiers are also lemmatised, and they contain the same data fields as shown above in Table 1. Again, lemmas are linked to specific wines on the website:

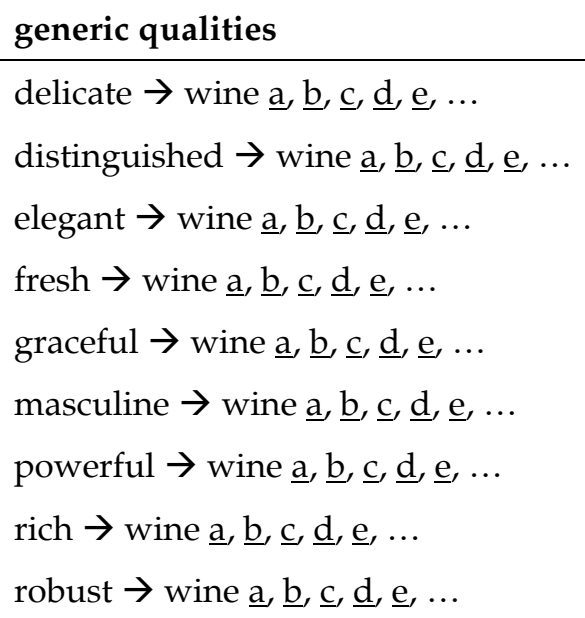

Table 3: Lemmatisation of qualifiers and linking to specific wines on the website 


\subsection{Cognitive situations}

It appears from a close study of course descriptions at the École des vins de Bourgogne (2013) that knowledge involved in wine tasting is complex and can be divided into five types: declarative knowledge, schematic knowledge, procedural knowledge, experiential knowledge, and ultimately, evaluative knowledge.

Declarative knowledge encompasses knowledge of the identity of the wine (status of the 'appellation contrôlée', position of the vineyard, varieties of grapes used, kind of vinification, ranking of the vintage and evolution in time, etc.). OB collects these data and addresses them to toponymic lemmas. All types of 'appellations contrôlées' (Regional, Villages, Premiers Crus, Grands Crus) as well as individual producers are lemmatised. All tasting characteristics are registered, and linking to wine tasting tutorials is provided:

\begin{tabular}{|l|}
\hline Chablis grand cru \\
\hline $\begin{array}{l}\text { Visual } \\
\text { White: pure green-gold in colour, evolving to a light yellow } \\
\text { with age. A wine with fine keeping properties (10-15 years, } \\
\text { sometimes more). }\end{array}$ \\
\hline $\begin{array}{l}\text { Nose } \\
\text { Intense mineral scents (flint) but with room for lime-flowers, } \\
\text { dried fruits, almond and a discreet touch of honey. Field mush- } \\
\text { room gives a strongly characteristic touch to this wine. }\end{array}$ \\
\hline $\begin{array}{l}\text { Palate } \\
\text { On the palate, acidity and fat are in perfect balance, as are live- } \\
\text { liness and dryness. It has all the charm of an inimitable and } \\
\text { authentic wine. }\end{array}$ \\
\hline $\begin{array}{l}\text { Global evaluation } \\
\text { This is the jewel in the crown of the chablis range, richly } \\
\text { nuanced by variations in "climat". }\end{array}$ \\
\hline $\begin{array}{l}\text { Link to wine tasting instruction video (tutorials) on the web- } \\
\text { site of BIVB }\end{array}$ \\
\hline
\end{tabular}

Table 4: Data addressed to specific wines

Schematic knowledge encompasses knowledge of relations between wine tasting terms and regions, appellations, and specific wines. In $\mathrm{OB}$, assistance is provided by wine tasting data being addressed to specific wines (cf. table 3 and 4 above). 
Procedural knowledge is the knowledge of the act of wine tasting itself: choice of the right type of glass, quantity of wine to be poured in it, serving temperature, etc. OB lemmatises all keywords connected to this kind of knowledge. Access will be supported by organising the data allowing systematic access through searches via keywords and table of contents (cf. table 5).

Since experiential knowledge is gained through personal experience, this type of knowledge cannot be represented in OB. OB cannot explain what it feels like to experience wine tasting, because tasting is such a complex and individual sensory experience. It might be argued, however, that the use of OB supports the gathering of experience, and hereby the acquisition of experiential knowledge.

Evaluative knowledge is the ultimate competence needed for wine tasting, and also the educational goal. It involves a range of cognitive processes in which the students become gradually capable of evaluating the wines: appraising, assessing, comparing and contrasting, criticising, grading, interpreting, and ranking them.

\subsection{Interpretive functions}

In $\mathrm{OB}$, the relevant interpretive situations are situations in which the intended user needs help in a wine tasting situation in order to interpret information and information conventions printed on the label. This information, regulated by law, also contains a commercial dimension (promotion of wine) and is extremely complex in Burgundy. It is planned that $\mathrm{OB}$ would provide direct access to the interpretation of wine labels using visual recognition software and make it available on smartphones. This will be achieved by the indexing of wine label data, both as generic data (for the recognition and interpretation of the main types of appellations) and as specific data (for the recognition of specific wines and wine growers).

\subsection{Operative situations}

Operative situations are situations in which the intended user needs immediate assistance to carry on the act of wine tasting. The data includes online instructions, recommendations, etc., and is presented in the form of an online wine tasting multimodal manual (texts and videos). Access is obtained through table of contents, questions and answers, and an indexation of related keywords, as shown in Table 5 below:

\begin{tabular}{|l|l|}
\hline questions & index of keywords \\
\hline What kind of glass? & glass \\
& \multicolumn{2}{c|}{$\begin{array}{l}\text { shape } \\
\text { volume } \\
\text { quality }\end{array}$} \\
\hline
\end{tabular}




\begin{tabular}{|l|l|}
\hline How much to pour into the glass? & pour \\
\hline Which temperature? & temperature \\
\hline How to hold on the glass? & hold \\
\hline How to swirl the glass? & swirl \\
\hline Where to look in the glass? & look $\begin{array}{l}\text { rims } \\
\text { sides }\end{array}$ \\
\hline
\end{tabular}

Table 5: Questions and index of keywords

\section{Dual access mode in $\mathrm{OB}$}

Online wine dictionaries like the wine glossary of VDB 2013 demonstrate two kinds of access to the data, namely consultation and navigation. Consultation, i.e. making queries to search and retrieve the data, is the default mode of dictionary use. Consultation is aimed at the appropriation of data, while navigation is aimed at the exploration of data. Navigation, in which the user follows hyperlinks to navigate between articles and pages, is normally the privilege of online dictionaries, but it should be noticed that it is also possible to navigate in paper dictionaries (Nau 2007), mainly by following internal links to other articles or to outer texts, or by simply reading articles for pleasure as a kind of lexicotainment.

\subsection{Consultation}

The consultation mode is characterised by the "I search" user behaviour. Consultation is motivated by a problem-based information need and aimed at the search for a solution to the encountered problem. The lexicographic relevance lies in the satisfaction of the information need. The point of departure of the search lies in a pre-formulated query. For instance, when a reader of a text on wine making encounters the term "astringency" the meaning of which is unclear them, they can make a search in the glossary on the VDB website, either analogically (through the alphabetic macrostructure of the glossary) or digitally (by typing the term in the query window and launching the search engine, which will return the information from the database). Consultation is goal-oriented because it is always aimed at getting a specific answer. The number of access routes (marked out by means of data structuring devices) is also limited. The access perspective is ruled by the lexicographer in so far as the answer to the query is given beforehand. Consultation is a modus operandi in which information is retrieved from relevant data presentation. Consultation belongs to the functionalist paradigm of information science, in which success 
or failure of information searches is measured after the use of the dictionary. Hereby the capacity of the dictionary - or lack of it - to satisfy the needs and fulfil the function is also measured. OB is designed to allow for this type of access in the foreseen user situations. Table 6 below shows the main characteristics of consultation:

\begin{tabular}{lr}
\hline & CONSUltation \\
\hline motivation & problem-driven information need \\
\hline relevance & satisfaction of need \\
\hline behaviour & search for data \\
\hline point of departure of query & preformulated \\
form of access & goal-oriented \\
\hline data structuring & mainly relational \\
\hline number of access routes & limited \\
dominating perspective & mainly lexicographer \\
information paradigm & functionalism \\
\hline
\end{tabular}

Table 6: Consultation mode in OB

\subsection{Navigation}

Navigation is the opposite of consultation. It is characterised by the "I do not search, I find" user behaviour and motivated by a pleasure-driven desire for information. In $\mathrm{OB}$, it is achieved, as explained above, through the multiple interlinking of the dictionary itself (the database) and the website of the BIVB:

\begin{tabular}{lr}
\hline & NAVIGATION \\
\hline motivation & pleasure-driven desire for information \\
\hline relevance & satisfaction of curiosity \\
\hline behaviour & discovery of data \\
\hline $\begin{array}{l}\text { point of departure of query } \\
\text { form of access }\end{array}$ & explone \\
\hline data structuring & mainly associative
\end{tabular}




\begin{tabular}{|rr}
\hline number of access routes & potentially unlimited \\
\hline dominating perspective & mainly user \\
\hline information paradigm & constructivism
\end{tabular}

Table 7: Navigation mode

Relevance lies in the satisfaction of the curiosity which drives the user to explore the data. There is no pre-formulated query or point of departure. The data are structured into associative networks, with a potentially unlimited number of access routes, and the user exposes themselves to data retrieval through discoveries being made along these routes. Access is of the exploratory kind, as neither a goal nor a logical path is needed. Access is guided by links and headings on the website, and routes are subject to fortuitous encounters generating pleasure. Navigation is ruled by the user perspective, as the access process itself is central, including obstacles, diversions and dead ends that can tease the user's curiosity and redirect them. Navigation belongs to the constructivist paradigm of information. In $\mathrm{OB}$, the functions involved in navigation are cognitive-oriented, as the purpose here is to acquire new knowledge, or to check on already existing knowledge in connection with wine tasting training programmes at the École des vins de Bourgogne.

\section{Conclusion}

In this article, it has been shown how an online subject-field-based wine dictionary (Van der Merwe 2008) could benefit from an expansion of its data and from integration with the resources of the websites of the South African wine industry. It could subsequently be transformed into an integrated information tool in order to satisfy even more efficiently the specific information needs of the intended user groups, particularly students and wine lovers. It has also been shown how a user-situation-based specialised lexicographic information tool, in this case OB, gathers multimodal data and provides monofunctional access to the data in order to satisfy the information needs of its intended users. Through integration with the website of the wine industry, OB offers a dual access mode - consultation and navigation - in order to help its users to get access to, or discover, the data that will help them learn how to verbalise the subtle nuances of wine tasting experience and to relate their knowledge of wine to the tasting itself in order to contextualise and enrich the experience. In this respect, OB is completely in line with what Béjoint (2010: 386) has in mind when predicting the transformation potential of online lexicography:

Probably the dictionary as we know it is on its way out, and we will see the emergence of new kinds of tools, reference tools encompassing more than the dictionary, containing other kinds of information and providing a better treatment of the more traditional presentations. 
OB is also in line with Prinsloo (2005: 11), who depicts this transformation even more accurately:

The great capacity and speed characteristics of electronic products, combined with enhanced query and data retrieval technology, indeed pave the way to a new generation of dictionaries unimagined in the paper-dictionary era.

In co-operation with the professionals of the wine industry, a proposal is made here to design online wine industry dictionaries that are truly integrated into the websites of the wine industry, wine boards and authorities, or with the websites of providers of wine tourism experiences (wine routes, visit to estates etc.). Websites of wine industry and wine tourism are indeed characterised by user-situation-based content management systems aiming at the satisfaction of the heterogeneous information needs of wine students, customers, lovers, visitors, etc. On such websites, data selection - and presentation - is to a large extent ruled by a user-situation-based (read: customer- and market-oriented) strategy: who is interested, in what, for what reasons, when, and how - being the crucial questions that have been answered in order to cater for the needs of the intended user groups. Such websites are not only sources of inspiration for lexicographic innovation, but also valuable information resources that can directly contribute to developing the functional quality of online wine industry dictionaries. Finally, it is worth noticing that the lexicographic proposals formulated in this article are not specific to wine industry. They also apply, without limitations, to the development of lexicographically structured information tools in other kinds of industries, sectors of the economy, corporations, and businesses: banking, insurance, real estate, medicine, technology and engineering, tourism, etc. Naturally, data differ, and so do priorities given to the specific user-situations involved, but the overall lexicographic principles for the online integration of user-situation identification, data selection, data access and data presentation remain identical.

\section{Note}

$+\quad$ As explained in the English version of VDB 2013: "The vineyard of Burgundy is made up of small plots known as climats and lieux-dits, pieced together like a mosaic. These give the Burgundy wine region its special character and rich diversity."

\section{Literature}

\section{Dictionaries and other lexicographically structured information tools}

DLV = Coutier, M. 2007. Le dictionnaire de la langue du vin. Paris: CNRS.

Drync Wine Free and Pro. 2013. Find and Manage Wine Online or on Your Mobile. http://www. drync.com/ (19/11/2010). 
École des vins de Bourgogne. 2013. http://www.ecoledesvins-bourgogne.com [accessed 30 August 2013]

GHV 2010. Guide Hachette des Vins. Paris: Hachette pratique.

GHV 2013. Guide Hachette des Vins. Paris: Hachette pratique. http://www.hachette-vins.com/leguide-hachette-des-vins / [accessed 30 august 2013]

SAWIS. 2013. S.A. Wine Industry Information and Systems NPC. http://www.sawis.co.za/ [last seen 1 June 2013]

VDB. 2013. Vins de Bourgogne. Le site officiel des vins de Bourgogne. Bureau Interprofessionnel des Vins de Bourgogne. Beaune Cedex. http://www.vins-bourgogne.fr/ [accessed 1 June 2013].

Winetech and SAWIS. 2012. South African Trilingual Wine Industry Dictionary http://www.sawis.co. za/dictionary/index.php [accessed 1 June 2013].

Wikipedia. 2013. Portail de la vigne et $d u$ vin. http://fr.wikipedia.org/wiki/Portail:Vigne_et_vin [accessed 1 June 2013].

Wine.co.za. 2013. Virtual Home of South African Wine. http://www.wine.co.za/ [last seen: 1 June 2013]

\section{Theoretical contributions}

Béjoint, H. 2010. The Lexicography of English. Oxford: Oxford University Press.

Bergenholtz, H. and U. Kaufmann. 1997. Terminography and Lexicography. A Critical Survey of Dictionaries from a Single Specialised Field. Tarp, S. (Ed.). 1997. Specialised Lexicography and Terminology. Hermes 18: 91-125.

Bergenholtz, H. and S. Tarp. 2010. LSL Lexicography or Terminography? The Lexicographer's Point of View. Fuertes-Olivera, P.A. (Ed.). 2010: 27-36.

Carstensen, S. 1989. Zur Darstellung kulturgebundener Wörter in der zweisprachigen Lexikographie. Kopenhagener Beiträge zur Germanistischen Linguistik 25: 5-21.

Fata, I. 2010. The Bilingual Specialised Translation Dictionary for Learners. Fuertes-Olivera, P. and H. Bergenholtz. 2010. Specialised Dictionaries for Learners: 83-103. Lexicographica. Series Maior 136. Berlin/New York: De Gruyter.

Fuertes-Olivera, P.A. (Ed.). 2010. Specialised Dictionaries for Learners. Lexicographica. Series Maior 136. Berlin/New York: De Gruyter.

Fuertes-Olivera, P.A. and H. Bergenholtz (Eds.). 2011a. e-Lexicography: The Internet, Digital Initiatives and Lexicography. London/New York: Continuum.

Fuertes-Olivera, P.A. and H. Bergenholtz. 2011b. Introduction: The Construction of Internet Dictionaries. Fuertes-Olivera, P.A. and H. Bergenholtz (Eds.). 2011: 1-16.

Fuertes-Olivera, P.A. and S. Tarp. 2014. Theory and Practice of Specialised Online Dictionaries: Lexicography versus Terminography. Berlin/New York: De Gruyter. [to appear]

Gouws, R. and P. Leroyer. 2009. Verhoogde leksikografiese toeganklikheid in die oorgang van ' $n$ toeristewoordeboek na 'n toeristegids as naslaanbron. Tydskrif vir Geesteswetenskappe 49(1): 145-159.

Granger, S. and M. Paquot (Eds.). 2012. Electronic Lexicography. Oxford: Oxford University Press.

Leroyer, P. 2008. Du support d'information à l'outil lexicographique: la lexicographisation du guide touristique. Bernal, E. and J. DeCesaris (Eds.). 2008. Proceedings of the XIII EURALEX Interna- 
tional Congress, Barcelona, 15-19 July 2008: 879-886. Sèrie Activitats 20. Barcelona: Universitat Pompeu Fabra, Institut Universitari de Lingüística Aplicada.

Leroyer, P. 2011. Change of Paradigm: From Linguistics to Information Science and from Dictionaries to Lexicographical Information Tools. Fuertes-Olivera, P.A. and H. Bergenholtz (Eds.). 2011: 121-140.

Leroyer, P. and H. Bergenholtz. 2014. Métalexicographie culturelle, fonctions lexicographiques et finalité pragmatique. Études de linguistique appliquée. [To appear.]

Leroyer, P. and R. Gouws. 2009. En termes de vin - Modularisation lexicographique du guide œnotouristique en ligne. Revue Française de Linguistique Appliquée 14(2): 99-116.

Lipovetsky, G. 2006. Le bonheur paradoxal. Essai sur la société d'hyperconsommation. Paris: Gallimard.

Nau, J.-Y. 2007. Revue de Coutier, Martine. Dictionnaire de la langue du vin. Le Monde des livres, 21 September 2007.

Prinsloo, D.J. 2005. Electronic Dictionaries Viewed from South Africa. Hermes 34: 11-35.

Tarp, S. 2008a. Lexicography in the Borderland between Knowledge and Non-knowledge. General Lexicographical Theory with Particular Focus on Learner's Lexicography. Lexicographica. Series Maior 134. Tübingen: Max Niemeyer.

Tarp, S. 2008b. The Third Leg of Two-legged Lexicography. Hermes. Journal of Language and Communication Studies 40: 117-131.

Tarp, S. 2012. Online Dictionaries: Today and Tomorrow. Lexicographica 28(1): 253-268.

Van der Merwe, M.F. 2008. Wine and Words: A Trilingual Wine Dictionary for South Africa. Lexikos 18: 337-348. 